\title{
COMPARISON OF SELECTIVE AND NON SELECTIVE CYCLO-OXYGENASE 2 INHIBITORS IN EXPERIMENTAL COLITIS EXACERBATION:
} role of leukotriene B4 and superoxide dismutase

\author{
José Wander BREGANÓ ${ }^{1}$, Décio Sabbatini BARBOSA ${ }^{1}$, Mirian Zebian El KADRI ${ }^{2}$,

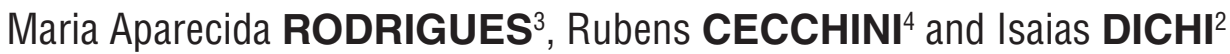

\begin{abstract}
Context - Nonsteroidal anti-inflammatory drugs are considered one of the most important causes of reactivation of inflammatory bowel disease. With regard to selective cyclo-oxygenase 2 inhibitors, the results are controversial in experimental colitis as well as in human studies. Objective - The aim this study is to compare nonsteroidal anti-inflammatory drugs effects, selective and non selective cyclo-oxygenase 2 inhibitors, in experimental colitis and contribute to the understanding of the mechanisms which nonsteroidal anti-inflammatory drugs provoke colitis exacerbation. Methods - Six groups of rats: without colitis, with colitis, and colitis treated with celecoxib, ketoprofen, indometacin or diclofenac. Survival rates, hemoglobin, plasmatic albumin, colonic tissue of interleukin-1B, interleukin-6, tumor necrosis factor alpha, prostaglandin E2, catalase, superoxide dismutase, thiobarbituric acid-reactive substances, chemiluminescence induced by tert-butil hydroperoxides, and tissue and plasmatic leukotriene B4 were determined. Results - The groups treated with diclofenac or indometacin presented lower survival rates, hemoglobin and albumin, higher tissue and plasmatic leukotriene B4 and tissue superoxide dismutase than the group treated with celecoxib. Ketoprofen presented an intermediary behavior between diclofenac/indometacin and celecoxib, concerning to survival rate and albumin. The groups without colitis, with colitis and with colitis treated with celecoxib showed leukotriene B4 and superoxide dismutase lower levels than the groups treated with nonselective cyclo-oxygenase 2 inhibitors. Conclusions - Diclofenac and indometacin presented the highest degree of induced colitis exacerbation with nonsteroidal anti-inflammatory drugs, celecoxib did not show colitis exacerbation, and ketoprofen presented an intermediary behavior between diclofenac/indometacin and celecoxib. These results suggest that leukotriene B4 and superoxide dismutase can be involved in the exacerbation of experimental colitis by nonselective nonsteroidal anti-inflammatory drugs.
\end{abstract}

HEADINGS - Colitis. Non-steroidal anti-inflammatory agents. Eicosanoids. Oxidative stress.

\section{INTRODUCTION}

Inflammatory bowel disease (IBD) is characterized by periods of remission and reactivation, and ingestion of nonsteroidal anti-inflammatory drugs (NSAIDs) is considered one of the most important causes of reactivation ${ }^{(14)}$. Extra-intestinal inflammatory features, as peripheral arthritis, are common and NSAID prescription may occurs even as self medication $^{(4,24)}$.

Although the exact pathophysiology of exacerbation of colitis by non-steroidal anti-inflammatory drugs remains unresolved, it is likely that eicosanoids, through a colonic Prostaglandin E2 suppression accompanied or not by a compensatory increase in leukotriene B4, play a fundamental role ${ }^{(14)}$. An issue that must be considered is the intensity of inhibition on ciclooxygenase $1(\mathrm{COX}-1)$ and ciclooxygenase 2 (COX-2), which greatly varies in accordance with NSAIDs type and dose. There are NSAIDs with low selectivity for COX-2, which practically inhibit COX-1 and COX-2 in the same proportion, whereas other NSAIDs, can have a 50 fold higher selectivity for COX-2 when compared to inhibition of COX$1^{(57,58)}$. Therefore, NSAIDs behavior may have distinguished consequences in arachdonic acid metabolism with distinct eicosanoids production, mainly in Prostaglandin E2 (PGE2) and leukotriene B4 (LTB4),

Declared conflict of interest of all authors: none

This study was financially supported by Research Funds of University of Londrina (FAEPE)

Departamento de Patologia, Análises Clínicas e Toxicológicas, Universidade de Londrina, PR; ${ }^{2}$ Departamento de Medicina Interna, Universidade de Londrina, PR; Departamento de Patologia, Faculdade de Medicina, Universidade Estadual de São Paulo, Botucatu, SP: ${ }^{4}$ Laboratorio de Fisiopatologia de Radicais Livres, Universidade de Londrina, PR. Brasil.

Correspondence: José Wander Breganó. Departamento de Patologia, Análises Clínicas e Toxicológicas, Centro de Ciências da Saúde, Hospital Universitário, Universidade Estadual de Londrina. Avenida Robert Koch, 60. CEP: 86038-440, Londrina, PR, Brasil. E-mail: wbregano@gmail.com 
and thus each NSAID can interfere in a particular way in IBD reactivation.

Whereas the literature about IBD reactivation with classical NSAIDs, like indometacin and diclofenac is extensive ${ }^{(10,35)}$, case reports with ketoprofen are scarce ${ }^{(52)}$. With regard to plasmatic selective inhibitors, the results are controversial in experimental colitis as well as in human studies. Some studies have verified that induced colitis in rats treated with a highly selective COX-2 inhibitor (L745.337)(46) or celecoxib ${ }^{(49,59)}$ provoked PGE2 reduction, inflammatory colonic exacerbation and low survival rates. Those authors concluded that prostaglandins derived from $\mathrm{COX}-2$ could have a defense role in colon protection. Matuk et al. ${ }^{(33)}$ also verified that a selective COX-2 inhibitor was highly associated with IBD reactivation in humans, and that drug discontinuation resulted in asymptomatic patients in 38\%. Nevertheless, Cuzzocrea et al. ${ }^{(9)}$ verified a reduction in colitis severity, shown by survival rate, colonic injury, and tumor necrosis factor- $\alpha(\mathrm{TNF} \alpha)$ and Interleukin-1 (IL-1) production in rats with trinitrobenzene sulfonic acid (TNBS) induced colitis and treated with celecoxib. Also in humans, Mahadevan et al..$^{(31)}$, Takeuchi et al. ${ }^{(51)}$ and Meidany et al. ${ }^{(12)}$ have not associated celecoxib, rofecoxib, nimesulide and etoricoxib utilization to the inflammatory response exacerbation in patients with IBD.

On the other hand, it has also been proposed that inflammatory bowel disease (IBD) results from an imbalance between pro-oxidant and antioxidant mechanisms ${ }^{(5,18,48)}$. Oxidative stress can result from excess production of reactive oxygen and nitrogen species (RONS) by inappropriate activation of phagocytic cells. Excessive liberation of RONS by polymorphonuclear cells is considered the main mechanism for colonic lesion in ulcerative colitis (UC), where accentuated lipid peroxidation occurs ${ }^{(48)}$. It has also been suggested that imbalanced and inefficient endogenous antioxidant response, especially attributed to SOD dual role acting as superoxide anion scavenger and an $\mathrm{H}_{2} \mathrm{O}_{2}$ producer, may contribute to both the pathogenesis and the perpetuation of the inflammatory processes ${ }^{(27)}$. Therefore, the aim of the present study is to assess celecoxib, ketoprofen, and other NSAIDs effects in experimental colitis, verify which NSAIDs exacerbate the disease and contribute to the understanding of the mechanisms responsible for colitis reactivation.

\section{METHODS}

\section{Animal and induction of colitis}

Adult male Wistar rats weighing $229 \pm 20 \mathrm{~g}$ were purchased from the Animal House of the Biological Sciences Center at the University of Londrina. They were housed five per cage, deprived of food for $24 \mathrm{hr}$, and colitis was induced following the procedure described by Morris et al. ${ }^{(37)}$. Rats were anesthetized with both xilazine $(10 \mathrm{mg} / \mathrm{Kg}, \mathrm{im})$ and ketamine $(50 \mathrm{mg} / \mathrm{Kg}$, im); polyurethane catheter $(2 \mathrm{~mm}$ of diameter) was inserted intrarectally into the colon such that the tip was located $8 \mathrm{~cm}$ proximal to the anus. One milliliter of TNBS (Sigma, St. Louis,Missouri-USA) in 40\% ethanol $(\mathrm{v} / \mathrm{v})$ was instilled into the lumen of the colon through the rubber catheter at a dose of $80 \mathrm{mg} / \mathrm{kg}$ body weight. The instillation procedure required 60 seconds and treated rats were kept in the Trendelenburg position to facilitate internal access of the TNBS solution. All experimental protocols described in this report were approved by the Animal Care Committee of the University of Londrina in accordance with the Law 11.794/2008 of October 8, 2008 and the rules of the Brazilian Society of Laboratory Animal Science - SBCAL/ Council on the Control of Animal Experiments - CONCEA. The method of euthanasia was by exsanguination by cardiac puncture after general anesthesia with both xilazine $(10 \mathrm{mg} /$ $\mathrm{kg}$, im) and ketamine $(50 \mathrm{mg} / \mathrm{kg}$, im).

\section{Animal groups and treatment}

Two separated experiments were performed: the first for studying oxidative stress, and the second for determination of interleukins and eicosanoids. In each experiment the rats were randomly divided into six groups: control group was constituted by animals without colitis; colitis group was constituted by animals with colitis, colitis+celecoxib group was constituted by animals with colitis and treated orally with celecoxib (15 $\mathrm{mg} / \mathrm{kg}$ ), colitis + ketoprofen group was constituted by animals with colitis and treated orally with ketoprofen $(10 \mathrm{mg} / \mathrm{kg})$, colitis+indometacin group was constituted by animals with colitis and treated orally with indometacin $(5 \mathrm{mg} / \mathrm{kg})$, and colitis+diclofenac group was constituted by animals with colitis and treated orally with diclofenac $(10 \mathrm{mg} / \mathrm{kg})$. All nonsteroidal anti-nflammatory drugs (NSAIDs) were suspended in a vehicle of $0.5 \%$ of carboxymethylcellulose. Treatment with different NSAIDs began $3 \mathrm{~h}$ before induction of colitis and continued every $12 \mathrm{~h}$ thereafter for up to $5 \mathrm{~d}$. The doses were selected because it has been shown to exert significant antiinflammatory effects in rats ${ }^{(6,38,46,53,55)}$. The others groups were treated orally with $0.5 \%$ carboxymethylcellose with the same periodicity. All samples of colon and blood were obtained on the 6th day after the induction of colitis.

\section{Evaluation of colon damage and sample preparation}

On the 6 day after the induction of colitis the rats were anesthetized and the colon was rapidly excised, approximately $10 \mathrm{~cm}$ proximal to the anus, slit longitudinally and gently rinsed with $10 \mathrm{mM}, \mathrm{pH} 7.4$, sodium phosphate buffer (SPB). Then, the segment was placed on a flat glass plate with the mucosal surface up. The degree of damage was scored macroscopically based on the presence of adhesions, strictures, ulcers, and wall thickness by an observer blinded to the treatment the rats had received ${ }^{(53)}$. Soon after, in order to study the oxidative stress, the mucosa was scraped off with a microscope slide onto a cold Petri dish and all mucosa specimens were frozen in liquid nitrogen. Samples were homogenized in SPB $(5 \mathrm{~mL})$ using a mechanical PotterElvejhem. The total homogenate obtained was used for thiobarbituric acid reactive substances (TBARS) and tert butyl hydroperoxide-initiated chemiluminescence (CL-LOOH) measurement. The supernatant of the total homogenate of colonic mucosa was obtained by centrifugation of the total homogenate for $10 \mathrm{~min}$ at $4{ }^{\circ} \mathrm{C}$ and $3,000 \mathrm{~g}$. In the second 
experiment to determine interleukins and eicosanoids, colon was removed (approximately $10 \mathrm{~cm}$ ), slit longitudinally and gently rinsed with SPB. Immediately, samples were processed by the Potter-Elvejhem with $2,5 \mathrm{~mL}$ of SPB and were centrifuged for $10 \mathrm{~min}$ at $4^{\circ} \mathrm{C}$ and $3,000 \mathrm{~g}$ and the supernatants were quickly immersed in dry ice and kept in freezer at $-70^{\circ} \mathrm{C}$.

\section{Histological analysis}

Samples of colon were isolated and immersed in 4\% paraformaldehyde in phosphate-buffered solution, dehydrated in ethanol, and embedded in parafilm. Sections of $4 \mu \mathrm{m}$ were stained with hematoxylin and eosin, and investigated by light microscopy for the presence of inflammatory changes. Inflammation was classified as mild, moderate or severe by pre established criterion that considered neutrophils and macrophages infiltration in tissue.

\section{Blood sampling}

The blood was obtained by cardiac punction and collected in tubes containing ethylene-diamine-tetraacetic acid (EDTA) for hemoglobin determination or tubes without anticoagulant for other determinations, kept on melting ice during transfer and immediately processed to obtain serum.

\section{Laboratorial parameters}

The following laboratorial parameters were determined: haemoglobin was determined by automated counter (Pentra 120 Retic, ABX) and albumin, alkaline phosphatase (AP) and $\gamma$-glutamyl transferase $(\gamma$-GT) were measured with automatic chemistry analyzer (Dimension AR, Dade-Behring). The results of these enzymes were expressed in U/100 $\mathrm{mg}$ of protein.

\section{Myeloperoxidase}

Myeloperoxidase (MPO) activity in colonic mucosa was determined using a modified method by Nieto et al. ${ }^{(40)}$. One unit of activity was defined as the amount of enzyme present that produces a change in absorbance per minute of 1.0 at $37^{\circ} \mathrm{C}$ in the final reaction volume containing the sodium acetate. The results were expressed in units per $100 \mathrm{mg}$ of protein (U/100 $\mathrm{mg}$ of protein).

\section{Oxidative stress analysis}

Analysis of tert butyl hydroperoxide-initiated-chemiluminescence in total homogenate of mucosa

The CL-LOOH in total homogenate of mucosa was evaluated as described previously by Gonzalez-Flecha et al. ${ }^{(17)}$. For chemiluminescence measurement, reaction mixtures were placed in $20 \mathrm{~mL}$ scintillation vials (low-potassium glass) containing final concentrations of: serum or homogenate $(250 \mu \mathrm{L}), 30 \mathrm{mM} \mathrm{KH} 2 \mathrm{PO} 4 / \mathrm{K} 2 \mathrm{HPO} 4$ buffer (pH 7.5), and $120 \mathrm{mM} \mathrm{KCl}$ with $3 \mathrm{mM}$ of tert butyl hydroperoxide in a final volume of $2 \mathrm{~mL}$. Tert butyl hydroperoxide-initiated chemiluminescence was measured in a Beckman LS 6000 liquid scintillation counter set to the out-of-coincidence mode, with a response range from 300 to $620 \mathrm{~nm}$. The vials were kept in the dark up to the moment of assay, and determination was carried out in a dark room at $30^{\circ} \mathrm{C}$. The results are expressed in counts per minute (cpm) or cpm for $100 \mathrm{mg}$ of protein (cpm/100 mg of protein).

\section{Thiobarbituric acid-reactive substances in total homogenate of mucosa}

The TBARS were measured by method as described by Jentzsch et al. ${ }^{(22)}$, using a high concentration of butylated hydroxytoluene before heating and differential readings at 535 and $572 \mathrm{~nm}$, which substantially improved its specificity. The results were expressed in $\mu \mathrm{mol}$ MDA/100 $\mathrm{mg}$ of protein.

\section{Activities of antioxidant enzymes SOD and CAT in the colonic mucosa}

The SOD activity was determined by the method proposed by Marklund and Marklund ${ }^{(32)}$ that is based on the enzyme capacity to inhibit autoxidation of pyrogalloll. The reaction was performed at $37^{\circ} \mathrm{C}$ and followed at $420 \mathrm{~nm}$, and the results were expressed in units/100 $\mathrm{mg}$ of protein (U/100 $\mathrm{mg}$ of protein).

The CAT activity was measured spectrophometrically at $240 \mathrm{~nm}$, by decomposition of $\mathrm{H}_{2} \mathrm{O}_{2}$ at $25 \mathrm{oC} \mathrm{C}^{(1)}$. The decomposition of $\mathrm{H}_{2} \mathrm{O}_{2}$ is proportional to the concentrations of enzyme and substrate, and the results were expressed as the difference in absorbance per $100 \mathrm{mg}$ of protein/minutes (DABS/100 $\mathrm{mg}$ of protein/min).

\section{Cytokines and eicosanoids analysis in the colonic mucosa or serum}

Interleukin-1 $B$ (IL-1 $B$ ), interleukin-6 (IL-6), tumor necrosis factor- $\alpha(\mathrm{TNF} \alpha)$, leukotriene B4 (LTB4) and Prostaglandin E2 (PGE2) concentration were measured by specific enzyme-linked immunosorbent assay (ELISA) according to the manufacturer's recommendation (R\&D System, Inc. Minneapolis,USA). The antibodies used for these cytokines and eicosanoids evaluations were: PGE2 - Capture antibody: goat anti-mouse polycronal antibody, detection antibody: antibody mouse monoclonal antibody to PGE2; IL-6 - Capture antibody: mouse anti-rat IL-6 monoclonal antibody, detection antibody: goat polycronal anti-rat to IL-6; IL-1ß - Capture Antibody: goat anti-rat IL-1ß polycronal antibody, detection antibody: goat polycronal anti-rat IL-1B; LTB4 - Capture antibody: rabbit anti-chicken polyclonal antibody, detection antibody: chicken polycronal antibody to LTB4 and TNFa - Capture Antibody: mouse anti-rat TNFa monoclonal antibody, detection antibody: goat polycronal anti-rat TNF $\alpha$.

The results were expressed in $\mathrm{pg} / \mathrm{mL}$ or pg per $100 \mathrm{mg}$ of protein ( $\mathrm{pg} / 100 \mathrm{mg}$ of protein) when determined in the serum or colonic mucosa, respectively.

\section{Statistical analysis}

All data are expressed as mean \pm SD. The results were analyzed by one-way analysis of variance followed by a Tukey-Kramer post hoc test for multiple comparisons for parametric values and Dunn's test for nonparametric values. Survival rates and histological score among groups were compared using the Fisher's exact test. Differences were considered to be significant when $P<0.05$. 


\section{RESULTS}

Survival rate and macroscopic scoring of colonic damage

The groups with colitis treated with diclofenac (31\%) and indometacin (44\%) presented the lowest rate of survival at the end of the experiment $(P<0.05$ in relation to all other groups). The survival rate was $88 \%$ in the colitis group treated with ketoprofen, whereas the groups without colitis, with colitis, and colitis treated with celecoxib had no mortality (Figure 1).

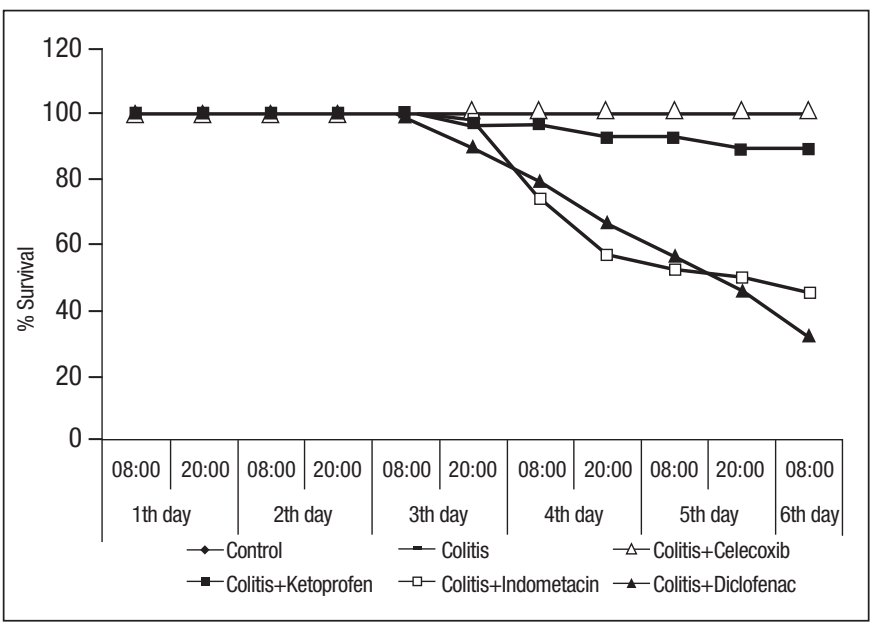

FIGURE 1. Survival rates (\%) after 6 days in rats with colitis and treated with different nonsteroidal anti-inflammatory drugs. $\mathrm{n}^{3} 10$ for each group of rats. Survival rates were significantly lower in the colitis groups treated with indometacin or diclofenac when compared to the other groups $(P<0.05$, Fisher's exact test $)$.

Macroscopic analysis of colonic damage showed a statistically significant difference in the group without colitis in relation to the colitis groups $(P<0.05)$. The group with colitis treated with indometacin and diclofenac showed a higher macroscopic score $(P<0.05)$ than the group colitis (Table 1$)$.

\section{Histological analysis}

The histology of the colon was severely affected in animal with colitis. The colitis was characterized by a massive immune cell infiltration, ulceration, and necrosis. The inflammatory response was mainly formed by neutrophils and macrophages, whereas limphocytes and plasmocytes were rarely observed. The presence of severe inflammation in the colonic mucosa was accompanied by an inflammatory reaction in the peritoneum. The control group showed no inflammation. In relation to the group without colitis, the groups with colitis, and colitis treated with celecoxib or ketoprofen presented mild inflammation $(P<0.05)$, whereas the groups with colitis treated with indometacin or diclofenac had severe inflammation $(P<0.05)$ in relation to the two later groups (data not shown).

\section{Enzymatic markers of colonic damage}

AP and MPO activities in the colonic tissue showed statistically significant differences in the colitis groups compared with the control group $(P<0.05) . \gamma$-GT activity was the only enzymatic marker that discriminated significantly the group with colitis treated with celecoxib which showed lower significant values $(P<0.05)$ when compared to the colitis groups treated with indometacin or diclofenac (Table 1).

\section{Blood markers of inflammatory activity (hemoglobin and albumin)}

All groups with colitis showed a significant reduction in plasma albumin in relation to the control group $(P<0.001)$. There were statistically significant differences $(P<0.05)$ in plasma albumin in the groups with colitis treated with indometacin or diclofenac in relation to the groups with colitis and colitis treated with celecoxib or ketoprofen (Table 1).

In relation to the control group, the colitis group, and the colitis group treated with celecoxib, there was a significant decrease $(P<0.05)$ in hemoglobin in the groups with colitis treated with ketoprofen, indometacin or diclofenac. The

TABLE 1. Markers of colonic damage and blood markers of inflammatory activity in rats with colitis and treated with different nonsteroidal anti-inflammatory drugs

\begin{tabular}{|c|c|c|c|c|c|c|}
\hline \multirow[b]{2}{*}{ Parameters } & \multicolumn{6}{|c|}{ GROUPS } \\
\hline & Control & Colitis & $\begin{array}{l}\text { Colitis + } \\
\text { Celecoxib }\end{array}$ & $\begin{array}{c}\text { Colitis + } \\
\text { Ketoprofen }\end{array}$ & $\begin{array}{c}\text { Colitis }+ \\
\text { Indometacin }\end{array}$ & $\begin{array}{c}\text { Colitis + } \\
\text { Diclofenac }\end{array}$ \\
\hline $\begin{array}{l}\text { Macroscopic } \\
\text { Scoring }\end{array}$ & $\begin{array}{c}2.8 \pm 0.8 \\
\mathrm{a}^{*} \mathrm{~b}^{\dagger} \mathrm{c}^{\dagger} \mathrm{d}^{*} \mathrm{e}^{*}\end{array}$ & $\begin{array}{c}8.6 \pm 1.4 \\
d^{\ddagger} e^{*}\end{array}$ & $12.4 \pm 3.1$ & $12.1 \pm 1.9$ & $14.4 \pm 2.3$ & $16.5 \pm 3.4$ \\
\hline $\begin{array}{l}\text { AP } \\
\text { U/100mg protein }\end{array}$ & $\begin{array}{l}13.0 \pm 5.6 \\
a^{*} b^{\ddagger} c^{*} d^{\ddagger} e^{*}\end{array}$ & $450.0 \pm 104.6$ & $342.9 \pm 148.7$ & $427.5 \pm 197.3$ & $342.2 \pm 132.4$ & $371.1 \pm 74.6$ \\
\hline $\begin{array}{l}\text { g-GT } \\
\text { U/100mg protein }\end{array}$ & $\begin{array}{l}8.6 \pm 3.1 \\
a^{*} c^{\dagger} d^{*} e^{*}\end{array}$ & $62.0 \pm 20.9$ & $\begin{array}{c}38.6 \pm 10.4 \\
d^{\ddagger} e^{\ddagger}\end{array}$ & $64.3 \pm 19.1$ & $91.3 \pm 34.5$ & $79.2 \pm 18.1$ \\
\hline $\begin{array}{l}\text { MPO } \\
\text { U/100mg protein }\end{array}$ & $\begin{array}{c}115.3 \pm 52.5 \\
a^{*} b^{\dagger} c^{\ddagger} d^{\ddagger} e^{*}\end{array}$ & $611.1 \pm 249.2$ & $530.5 \pm 162.0$ & $440.5 \pm 170.8$ & $513.8 \pm 260.2$ & $562.0 \pm 219.9$ \\
\hline $\begin{array}{l}\text { Albumin } \\
\text { G/dL }\end{array}$ & $\begin{array}{c}1.53 \pm 0.11 \\
a^{\S} b^{\S} c^{\S} d^{\S} e^{\S}\end{array}$ & $\begin{array}{c}1.19 \pm 0.13 \\
c^{\S} d^{\S} e^{\S}\end{array}$ & $\begin{array}{l}1.10 \pm 0.17 \\
c^{* *} d^{\S} e^{\S}\end{array}$ & $\begin{array}{c}0.89 \pm 0.13 \\
e^{* *}\end{array}$ & $0.72 \pm 0.11$ & $0.68 \pm 0.08$ \\
\hline $\begin{array}{l}\text { Hemoglobin } \\
\text { G/dL }\end{array}$ & $\begin{array}{c}16.3 \pm 0.6 \\
c^{\S} \mathrm{d}^{\S} \mathrm{e}^{\S}\end{array}$ & $\begin{array}{c}16.8 \pm 1.1 \\
c^{\S} d^{\S} e^{\S}\end{array}$ & $\begin{array}{c}15.6 \pm 0.8 \\
c^{* *} d^{\S} e^{\S}\end{array}$ & $13.7 \pm 1.4$ & $11.9 \pm 1.0$ & $13.4 \pm 1.3$ \\
\hline
\end{tabular}

All values are mean \pm SD. AP: alkaline phosphatase; g-GT: g-glutamyl transferase; MPO: myeloperoxidase. The analyses were performed in the sixth day after colitis induced by TNBS and treatment with NSAIDs. $\mathrm{N}=10$ for each group of rats. a: in comparison to colitis group; b: in comparison to colitis + celecoxib group; c: in comparison to colitis + ketoprofen group; d: in comparison to colitis + indometacin group, and e: in comparison to colitis + diclofenac group. ${ }^{*} P<0.001$ by Dunn's test; ${ }^{\dagger} P<0.01$ by Dunn's test; ${ }^{\ddagger} P<0.05$ by Dunn's test; ${ }^{\circledR} P<0.001$ by Tukey-Kramer test ; ${ }^{* *} P<0.01$ by Tukey-Kramer test; ${ }^{\dagger \dagger} P<0.05$ by Tukey-Kramer test. 
lowest hemoglobin concentration was observed in the indometacin group which also showed a significant reduction $(P<0.05)$ in relation to the ketoprofen group (Table 1).

\section{Pro-oxidant and antioxidant markers of oxidative stress}

With respect to tissue pro-oxidant markers, CL-LOOH and TBARS measurements showed an increase $(P<0.05)$ in the colitis group and in all colitis groups treated with NSAIDs in relation to the control group (Table 2).

SOD enzymatic antioxidant activity was significantly higher $(P<0.05)$ in the colitis groups treated with ketoprofen, indometacin, and diclofenal than the control group and the colitis group (Table 2, Figure 2), whereas there was no statistically significant difference in CAT activity in the groups (Table 2).

\section{Cytokines and eicosanoids concentration in the colonic mucosa}

All colitis groups presented higher $(P<0.05)$ tissue IL-1B concentration when compared to the control group, whereas tissue IL-6 and TNF $\alpha$ concentration showed higher values in all colitis groups treated with NSAIDs than in the control group (Table 3).

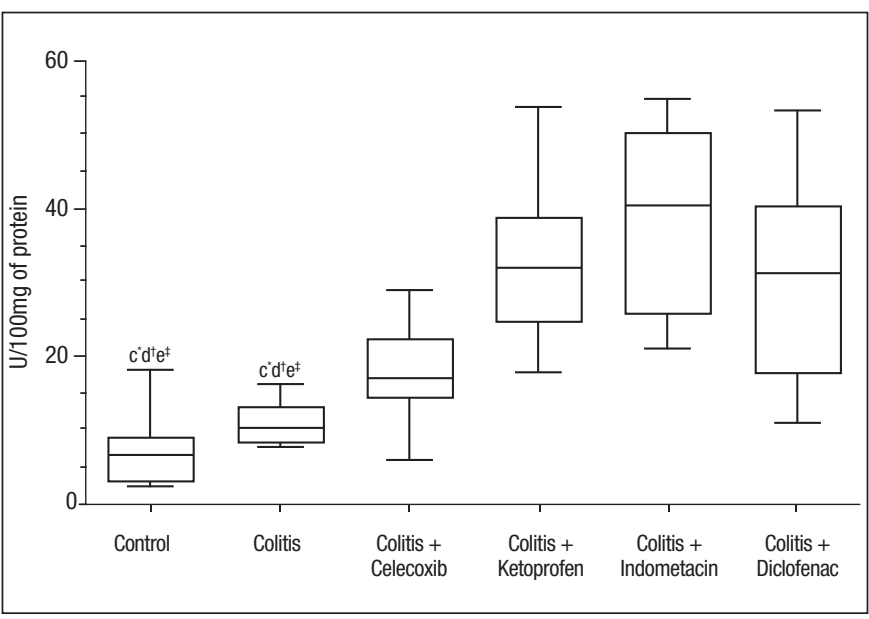

FIGURE 2. Superoxide dismutase (SOD) activity in the colonic mucosa in rats with colitis and treated with different nonsteroidal anti-inflammatory drugs. (Box-and-Whiske Plots). Evaluation was performed in the 6 day after colitis induction and beginning the treatment with NSAIDs. $\mathrm{n}=10$ for each group of rats. a: in comparison to colitis group; b: in comparison to colitis + celecoxib group; $\mathrm{c}$ : in comparison to colitis + cetoprofen group; $\mathrm{d}$ : in comparison to colitis + indometacin group, and e: in comparison to colitis + diclofenac group. ${ }^{*} P<0.001 ;{ }^{\dagger} P<0.01 ;{ }^{\ddagger} P<0.05$ by Dunn's test.

TABLE 2. Pro-oxidants and antioxidants markers in colonic mucosa in rats with colitis and treated with different nonsteroidal anti-inflammatory drugs

\begin{tabular}{|c|c|c|c|c|c|c|}
\hline \multirow[b]{2}{*}{ Parameters } & \multicolumn{6}{|c|}{ GROUPS } \\
\hline & Control & Colitis & $\begin{array}{l}\text { Colitis + } \\
\text { Celecoxib }\end{array}$ & $\begin{array}{l}\text { Colitis }+ \\
\text { Ketoprofen }\end{array}$ & $\begin{array}{c}\text { Colitis }+ \\
\text { Indometacin }\end{array}$ & $\begin{array}{l}\text { Colitis + } \\
\text { Diclofenac }\end{array}$ \\
\hline $\begin{array}{l}\text { CL-LOOH } \\
\text { cpm x } 1000 / 100 \mathrm{mg} \text { protein }\end{array}$ & $\begin{array}{l}4.1 \pm 1.6 \\
a^{*} b^{\dagger} c^{\ddagger} d^{*} e^{*}\end{array}$ & $23.6 \pm 6.9$ & $22.2 \pm 13.1$ & $20.3 \pm 7.1$ & $28.6 \pm 11.4$ & $26.3 \pm 9.3$ \\
\hline $\begin{array}{l}\text { TBARS } \\
10^{-3} \mathrm{mmol} \mathrm{MDA} / 100 \mathrm{mg} \text { protein }\end{array}$ & $\begin{array}{l}7.11 \pm 1.30 \\
\mathrm{a}^{\ddagger} \mathrm{b}^{\dagger} \mathrm{c}^{*} \mathrm{~d}^{\dagger} \mathrm{e}^{\ddagger}\end{array}$ & $11.94 \pm 1.84$ & $14.73 \pm 4.08$ & $14.76 \pm 3.81$ & $14.93 \pm 4.89$ & $13.5 \pm 3.55$ \\
\hline $\begin{array}{l}\text { SOD } \\
\text { U/100mg protein }\end{array}$ & $\begin{array}{l}7.2 \pm 5.0 \\
c^{*} \mathrm{~d}^{*} \mathrm{e}^{*}\end{array}$ & $\begin{array}{l}11.0 \pm 2.9 \\
c^{*} d^{*} e^{*}\end{array}$ & $18.0 \pm 6.9$ & $32.4 \pm 10.6$ & $38.3 \pm 12.8$ & $30.2 \pm 13.7$ \\
\hline $\begin{array}{l}\text { CAT } \\
\text { DABS/100 mg protein } / \mathrm{min}\end{array}$ & $0.255 \pm 0.079$ & $0.184 \pm 0.062$ & $0.256 \pm 0.085$ & $0.231 \pm 0.052$ & $0.241 \pm 0.069$ & $0.222 \pm 0.049$ \\
\hline
\end{tabular}

All values are mean \pm SD. CL-LOOH: tert butyl hydroperoxide-initiated-chemiluminescence; TBARS: thiobarbituric acid-reactive substances; SOD: superoxid dismutase; CAT: catalase. The analyses were performed in the sixth day after colitis induced by TNBS and treatment with NSAIDs. $\mathrm{N}=10$ for each group of rats. a: in comparison to colitis group; b: in comparison to colitis + celecoxib group; c: in comparison to colitis + Ketoprofen group; d: in comparison to colitis + indometacin group, and e: in comparison to colitis + diclofenac group. ${ }^{*} P<0.001$; ${ }^{\dagger} P<0.01$; ${ }^{\ddagger} P<0.05$ by Dunn's test.

TABLE 3. Cytokines concentration in rats with colitis and treated with different nonsteroidal anti-inflammatory drugs

\begin{tabular}{|c|c|c|c|c|c|c|c|c|}
\hline \multirow[b]{2}{*}{ Parameters } & \multirow[b]{2}{*}{ Samples } & \multirow[b]{2}{*}{ Units } & \multicolumn{6}{|c|}{ GROUPS } \\
\hline & & & Control & Colitis & $\begin{array}{c}\text { Colitis + } \\
\text { Celecoxib }\end{array}$ & $\begin{array}{c}\text { Colitis }+ \\
\text { Ketoprofen }\end{array}$ & $\begin{array}{c}\text { Colitis }+ \\
\text { Indometacin }\end{array}$ & $\begin{array}{c}\text { Colitis + } \\
\text { Diclofenac }\end{array}$ \\
\hline \multirow[t]{2}{*}{ LTB4 } & Serum & $\mathrm{pg} / \mathrm{mL}$ & $\begin{array}{c}761 \pm 390 \\
c^{*} \mathrm{~d}^{*} \mathrm{e}^{*}\end{array}$ & $\begin{array}{c}849 \pm 567 \\
c^{*} d^{*} e^{*}\end{array}$ & $\begin{array}{c}1642 \pm 621 \\
c^{\dagger} d^{\dagger} e^{*}\end{array}$ & $2930 \pm 935$ & $3052 \pm 862$ & $3324 \pm 862$ \\
\hline & Tissue & $\begin{array}{l}\mathrm{pg} / 100 \mathrm{mg} \\
\text { protein }\end{array}$ & $\begin{array}{c}352 \pm 229 \\
c^{\dagger} d^{\dagger} e^{\dagger}\end{array}$ & $695 \pm 201$ & $776 \pm 350$ & $954 \pm 418$ & $969 \pm 251$ & $958 \pm 433$ \\
\hline PGE2 & Tissue & $\begin{array}{l}\mathrm{pg} / 100 \mathrm{mg} \\
\text { protein }\end{array}$ & $\begin{array}{c}10328 \pm 1355 \\
b^{*} c^{*} d^{*} e^{*}\end{array}$ & $\begin{array}{c}9247 \pm 1036 \\
b^{*} c^{*} d^{*} e^{*}\end{array}$ & $\begin{array}{c}6318 \pm 1049 \\
c^{*} d^{*}\end{array}$ & $\begin{array}{c}3183 \pm 1108 \\
\mathrm{e}^{*}\end{array}$ & $\begin{array}{c}3946 \pm 855 \\
e^{\ddagger}\end{array}$ & $5608 \pm 952$ \\
\hline IL-1b & Tissue & $\begin{array}{l}\mathrm{pg} / 100 \mathrm{mg} \\
\text { protein }\end{array}$ & $\begin{array}{c}44.7 \pm 54.7 \\
a^{*} b^{*} c^{*} d^{*} e^{*}\end{array}$ & $264.9 \pm 27.0$ & $256.5 \pm 51.1$ & $254.1 \pm 58.9$ & $234.9 \pm 70.2$ & $296.1 \pm 70.8$ \\
\hline IL-6 & Tissue & $\mathrm{pg} / \mathrm{mL}$ & $\begin{array}{c}27.4 \pm 21.8 \\
\mathrm{~b}^{\dagger} \mathrm{c}^{\dagger} \mathrm{d}^{\dagger} \mathrm{e}^{*}\end{array}$ & $44.2 \pm 8.3$ & $57.5 \pm 16.0$ & $56.8 \pm 13.7$ & $54.2 \pm 16.7$ & $58.6 \pm 15.4$ \\
\hline TNF $\alpha$ & Tissue & $\mathrm{pg} / \mathrm{mL}$ & $\begin{array}{c}25.6 \pm 14.4 \\
b^{*} c^{\dagger} d^{\dagger} e^{*}\end{array}$ & $37.9 \pm 5.9$ & $55.0 \pm 15.3$ & $48.4 \pm 11.9$ & $49.5 \pm 16.0$ & $54.8 \pm 15.4$ \\
\hline
\end{tabular}

All values are mean \pm SD. IL-1 $\beta$ : interleukin 1 Beta; IL-6: interleukin 6, and TNF $\alpha$ : tumor necrosis factor alpha. The analyses were performed in the sixth day after colitis induced by TNBS and treatment with NSAIDs. $\mathrm{N}=10$ for each group of rats. a: in comparison to colitis group; b: in comparison to colitis + celecoxib group; $\mathrm{c}$ in comparison to colitis + Ketoprofen group; d: in comparison to colitis + indometacin group, and e: in comparison to colitis + diclofenac group. ${ }^{*} \mathrm{P}<0.001 ;{ }^{\dagger} \mathrm{P}<0.05 ;{ }^{\ddagger} \mathrm{P}<0.05$ by Tukey-Kramer test 
With regard to tissue PGE2 concentration, there was a significantly reduction $(P<0.001)$ in the colitis groups treated with NSAIDS in relation to the control group and the colitis group. Besides, colitis groups treated with ketoprofen or indometacin showed a lower significant concentration $(P<0.05)$ when compared to colitis group treated with celecoxib or diclofenac (Table 3, Figure 3). LTB4 tissue and plasmatic concentration showed higher values $(P<0.05)$ in colitis groups treated with ketoprofen, indometacin or diclofenac than in the control group. In the meantime, colitis group and colitis treated with celecoxib showed significant lower LTB4 plasmatic concentration than colitis groups treated with nonselective COX-2 inhibitors (Table 3, Figure 4).

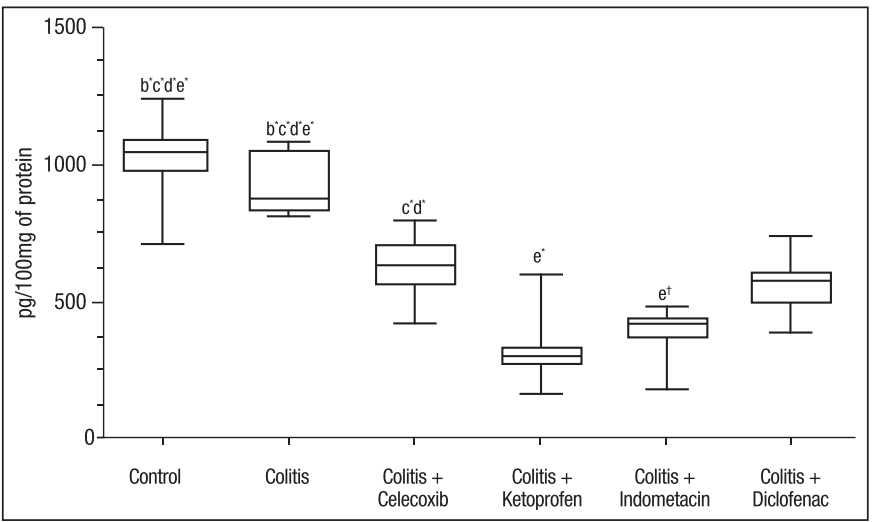

FIGURE 3. Protaglandin E2 (PGE2) concentration in the colonic mucosa obtained in rats with colitis and treated with different nonsteroidal antiinflammatory drugs (Box-and-Whiske Plots). Evaluation was performed in the 6 day after colitis induction and beginning the treatment with NSAIDs. $\mathrm{n}=10$ for each group of rats. a: in comparison to colitis group; b: in comparison to colitis + celecoxib group; c: in comparison to colitis + cetoprofen group; $\mathrm{d}$ : in comparison to colitis + indometacin group, and e: in comparison to colitis + diclofenac group. ${ }^{*} P<0.001 ;{ }^{\dagger} P<0.05$ by Tukey-Kramer test.

\section{DISCUSSION}

Exacerbation of inflammatory response in ulcerative colitis by nonsteroidal anti-inflammatory drugs in general, and specifically by indometacin and diclofenac, has been verified by several authors in case reports ${ }^{(10,51)}$ or in experimental colitis $^{(46,53)}$. In the current study, the exacerbation in the above mentioned NSAIDs was shown by decreased hemoglobin and plasma albumin concentration, macroscopic and histological higher colonic damage, and a high mortality incidence. These data are in agreement with very similar studies by Wallace et al. ${ }^{(53)}$ and Reuter et al. ${ }^{(46)}$. In the meantime, ketoprofen presented a lower inflammatory activity than indometacin and diclofenac measured by the aforementioned parameters, and a high survival rate $(88 \%)$, whereas celecoxib showed the lowest inflammatory exacerbation between the different NSAIDs with $100 \%$ of survival rate.

The reduction in hemoglobin concentration verified in the colitis groups treated with ketoprofen, indometacin, and diclofenac is likely due to intestinal losses through ulcerations. However, another possibility could be related to the inhibition of platelet aggregation, which depends on platelet capacity to yield tromboxane A2; as platelets do not have COX-2 activity, tromboxane A2 synthesis depends exclusively on COX-1 action. Therefore, celecoxib, a selective COX-2 inhibitor, does not interfere with platelet function ${ }^{(30)}$, whereas non selective NSAIDs, as ketoprofen ${ }^{(50)}$, indometacin ${ }^{(34)}$, and diclofenac ${ }^{(4)} \mathrm{do}$; thus, they could cause or amplify the intestinal bleeding. Meanwhile, decrease in serum albumin, which is used as an inflammatory marker in many diseases ${ }^{(16)}$, including inflammatory bowel disease ${ }^{(29)}$, verified in the colitis groups treated with indometacin and diclofenac is mainly due to higher vascular permeability, which in ulcerative colitis is systemic, that is, not limited to the local tissue injury ${ }^{(19,47)}$.

Experimental colitis induced by TNBS/ethanol is considered a good model for the study of ulcerative colitis in

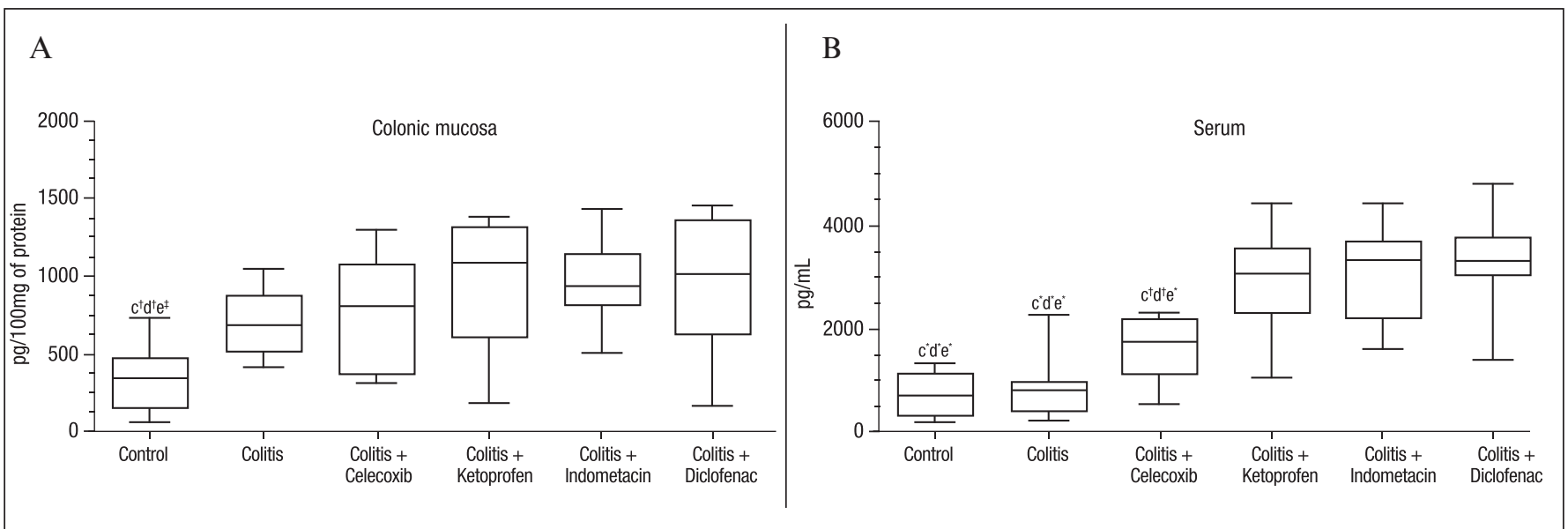

FIGURE 4. Leukotriene B4 concentration (LTB4) in the colonic mucosa and serum in rats with colitis and treated with different nonsteroidal anti-inflammatory drugs (Box-and-Whiske Plots). Evaluation was performed in the 6 day after colitis induction and beginning the treatment with NSAIDs. $\mathrm{n}=10$ for each group of rats. Statistical significance: $P<0,05$. (A): in comparison to colitis group; (B): in comparison to colitis + celecoxib group; c: in comparison to colitis + cetoprofen group; d: in comparison to colitis + indometacin group, and e: in comparison to colitis + diclofenac group. $P<0.001 ;{ }^{\dagger} P<0.01 ;{ }^{\ddagger} P<0.05$ by Tukey-Kramer test. 
$\operatorname{rats}^{(13,40,53)}$. In the present study, MPO, AP, and $\gamma$-GT activities in colonic mucosa were associated with macroscopic and histological analysis showing that colitis induction was accomplished in all animals. MPO is a constitutive enzyme of neutrophils, which is frequently used as a marker of polymorphonuclear infiltration in tissues, mainly in $\operatorname{colon}^{(9,41)}$. Similarly to the studies by Wallace et al. ${ }^{(53)}$ and Reuter et al. ${ }^{(46)}$ who used indometacin and diclofenac, MPO was unable to differentiate the responses of the colitis group with the colitis groups treated with different NSAIDs. Nevertheless, this enzyme showed colitis induction with a six fold increase in MPO activity in colitis group in relation to the control group. Similarly to the studies by Nieto et al. ${ }^{(40,41)}$, AP and $\gamma$-GT activities, other enzymatic markers of colonic damage, also showed increased concentration in the colitis group when compared to the control group. However, $\gamma$-GT was the only enzymatic marker which discriminated the lower tissue activity of colitis group treated with celecoxib in relation to the colitis groups treated with indometacin or diclofenac.

Nitric oxide $(\mathrm{NO} \bullet)$, superoxide $\left(\mathrm{O}_{2}{ }^{-\cdot}\right)$, peroxynitrite $\left(\mathrm{ONOO}^{-}\right)$, hydrogen peroxide $\left(\mathrm{H}_{2} \mathrm{O}_{2}\right)^{2}$, and hypochlorite $\left(\mathrm{OCL}^{-}\right)$, RONS produced mainly by phagocytic leukocytes present in inflamed mucosa, have been considered the pathogenic mechanism of mucosa damage, via lipid peroxidation in polyunsaturated fatty acids cellular membrane, being responsible for permeability alterations and cellular death ${ }^{(28)}$. The lipid peroxidation in tissue was quantified by the classic colorimetric test of thiobarbituric acid reactive substances (TBARS), and also with a more sensitive and specific test performed by chemiluminescence (CL-LOOH). Both methods have been used to measure lipid peroxidation in several tissues, including plasma ${ }^{(3,7,21)}$. Oxidized lipids increased concentration has been verified in colonic mucosa of patients with ulcerative colitis ${ }^{(26)}$ as well as in experimental colitis ${ }^{(21)}$. In the current study, both TBARS and LOOH showed higher values in colitis groups than in the control group. However, there were no significant differences between colitis groups, whether treated or not with NSAIDs.

With regard to the antioxidant enzymes, there were not observed significant differences in CAT activity in the studied groups, however, SOD activity increased in the colitis groups treated with ketoprofen, indometacin or diclofenac, the groups which presented the highest mortality rates, reduction in plasma albumin and hemoglobin levels, and increase in LTB4 concentration. SOD is an enzyme that can be induced by overproduction of $\mathrm{O}_{2}^{-\bullet}$ and has a dual role in oxidative stress, as $\mathrm{O}_{2} \bullet$ scavenger and also by producing $\mathrm{H}_{2} \mathrm{O}_{2}$ Thus, an isolated increase in SOD could deplete $\mathrm{O}^{-\bullet}$ at a cellular level, but also increase $\mathrm{H}_{2} \mathrm{O}_{2}$ production, contributing to lipid peroxidation, and consequently to tissue damage ${ }^{(26,27,42,45)}$. It has been demonstrated that $\mathrm{H}_{2} \mathrm{O}_{2}$ enhanced production could also stimulate neutrophils chemotaxis ${ }^{(25)}$, activate T lymphocyte ${ }^{(36)}$, and induce adhesion molecules expression ${ }^{(15)}$. Catalase transforms $\mathrm{H}_{2} \mathrm{O}_{2}$ in $\mathrm{H}_{2} \mathrm{O}$ and $\mathrm{O}_{2}$, thus it must follow SOD increase to yield inert products ${ }^{(27)}$. As CAT levels did not increase in the present study, it can be hypothesized that
SOD increase, in the above mentioned colitis groups could contribute to colitis exacerbation, acting like a pro-oxidant.

IL-1 $\beta$ and TNF $\alpha$, secreted mainly by macrophages, are considered IBD main mediators. They can exert several activities in the inflammatory response, as: activation, chemoatraction and neutrophils and macrophages adhesion, IL-6 and IL-8 induction, and RONS production ${ }^{(2,43)}$. IL-1 $B$ distinguished the control group from all the other groups, but did not discriminate inflammation severity among colitis groups treated with NSAIDs. The acute phase-reactants precursor, IL-6, considered a good marker to follow disease activity in IBD patients ${ }^{(39)}$, and $\mathrm{TNF} \alpha$, were also unable to differentiate inflammatory severity in the colitis groups.

In relation to eicosanoids, the decrease in PGE2 tissue concentration found in the colitis groups treated with NSAIDs was mainly verified with ketoprofen and indometacin. These data can be explained by the intensity of NSAIDs action to inhibit COX-1 and COX-2 activities. Warner et al. ${ }^{(57)}$ compared the inhibitory action of several NSAIDs on COX-1 and COX-2 activities, and verified, after obtaining COX-2 inhibition in $80 \%$, that indometacin and ketoprofen inhibit COX-1 activity approximately, in 90 and $95 \%$, respectively, whereas diclofenac and celecoxib in 70 and $60 \%$, respectively.

PGE2 decrease has been related to the exacerbation of the inflammatory response caused by NSAIDs in experimental colitis $^{(53)}$, since its normal concentration is important to maintain the physiologic functions of the colonic mucosa and inhibit IL-1, TNF $\alpha$, besides several adhesion molecules synthesis ${ }^{(56)}$. Moreover, Kandil et al. ${ }^{(23)}$ verified that PGE2 decreased concentration predisposed rats with experimental colitis to reactivate the disease, whereas the predisposition reduced when misoprostol, a PGE1 analog, was used. Nevertheless, in the present study, PGE2 reduction does not seem to be the main cause of the inflammatory activity exacerbation. This can be seen when colitis groups treated with celecoxib or ketoprofen were compared with colitis group treated with diclofenac. Although ketoprofen group presented lower PGE2 concentration than diclofenac group, and celecoxib group showed the same concentration, the colitis group treated with diclofenac showed a higher severity degree in several parameters, including mortality rate.

The increase in LTB4, concentration found in the colitis groups treated with non selective COX-2 inhibitors (ketoprofen, indometacin and diclofenac) is likely due to the action of these NSAIDs on arachdonic acid metabolism. The inhibition of ciclooxygenase pathway leads to a higher arachdonic acid degradation by the enzyme 5-lipooxygenase (5-LPO), resulting in an enhancement of leukotrienes production $^{(8)}$, including LTB4, a very important inflammatory mediator ${ }^{(11)}$. Besides promoting neutrophils influx to colonic mucosa, LTB4 stimulates ROS, $\mathrm{O}_{2}^{-}$by neutrophils, and $\mathrm{H}_{2} \mathrm{O}_{2}$ by macrophages ${ }^{(20)}$, thus contributing to oxidative stress and tissue damage. Conceivably, the increase in oxidative stress in the aforementioned groups was shown, in the current study, by SOD concentration. It has also been demonstrated that LTB4 intracolonic administration 
provokes increased tissue damage in rats with colitis and that LTB4 antagonist utilization as well as 5-LPO inhibitors can attenuate leukocytes adhesion and reduce colonic damage severity induced by NSAIDs ${ }^{(54)}$. In the present experiment, there were no significant differences in LTB4 concentration when the control group was compared to the colitis group, similarly to the results obtained by Nieto et al..$^{(41)}$ in experimental colitis induced by TNBS. However, Wallace et al. ${ }^{(53)}$ reported LTB4 increase in colitis group when compared with a control group (without colitis). Besides, the later authors did not find significant differences in LTB4 concentration when they compared a colitis group with a colitis group treated with indometacin. Thus, they concluded, differently from our results, that LTB4 was not related with exacerbation of the inflammatory response by NSAIDs.

Although, the literature about the subject tends to attribute the exacerbation of the inflammatory response just to one determinant factor, for example, decrease in PGE2 ${ }^{(23)}$, the results of the present study suggest that LTB4 increase provoked by NSAIDs, mainly by non selective COX-2 inhibitors, leads to neutrophils infiltration enhancement and RONS production. Oxidative stress increase leads to SOD augmentation and thereafter to $\mathrm{H}_{2} \mathrm{O}_{2}$ increase, which provokes greater tissue damage and consequently loss of mucosa barrier functions, leading ultimately to an enhancement of the inflammatory response. PGE2 reduction could affect the physiological maintenance of the mucosa barrier, mucosa cicatrisation, as well as a decrease in PGE2 capacity in modulating the inflammatory response due to reduction of its inhibitory effects on the inflammatory cytokines IL-1 and TNFa. This picture points out to the importance of eicosanoids-RONS interaction as a physiopathological factor in the colitis exacerbation by different NSAIDs.

In general, hemoglobin and plasma albumin concentration, macroscopic and histological colonic damage, and mortality incidence showed that celecoxib is the NSAID which does not exacerbate experimental colitis; ketoprofen presented an intermediary behavior between diclofenac/indometacin and celecoxib, concerning only to survival rate and albumin levels, whereas indometacin and diclofenac are the most devastating NSAIDs. Furthermore, the present study suggests that LTB4 and SOD are involved in the exacerbation of experimental colitis by nonselective NSAIDs.

\section{ACKNOWLEDGMENTS}

This study was financially supported by Research Funds of University of Londrina (FAEPE).

Breganó JW, Barbosa DS, Kadri MZ, Rodrigues MA, Cecchini R, Dichi I. Comparação dos inibidores seletivos e não seletivos da ciclo-oxigenage 2 na exacerbação da colite experimental: papel do leucotrieno B4 e superóxido dismutase. Arq Gastroenterol. 2014,51(3):226-34.

RESUMO - Contexto - Os anti-inflamatórios não-esteróides são considerados uma das mais importantes causas de reativação da doença inflamatória intestinal. Em relação aos inibidores seletivos da ciclo-oxigenase 2, os resultados são controversos tanto em estudos envolvendo humanos como na colite experimental. Objetivo - Comparar os efeitos dos anti-inflamatórios não-esteróides, seletivos e não seletivos da ciclo-oxigenase 2, na colite experimental e, contribuir para o entendimento do mecanismo no qual os anti-inflamatórios não-esteróides provocam a exacerbação da colite. $M \boldsymbol{e}^{-}$ todo - Seis grupos de ratos foram estudados: sem colite, com colite e com colite e tratados com celecoxib, cetoprofeno, indometacina ou diclofenaco. Foram determinadas a taxa de sobrevida, as concentrações de hemoglobina e albumina plasmática, as concentrações teciduais na mucosa colônica de interleucina-1B, interleucina-6, fator de necrose tumoral alfa, prostaglandina E2, catalase, superóxido dismutase, substâncias reativas ao ácido tiobarbitúrico e quimiluminescência estimulada por hidroperóxido de tert-butil, e as concentraçãos plasmática e tecidual de leucotrieno B4. Resultados - O grupo tratado com diclofenaco ou indometacina apresentaram as menores taxas de sobrevida, concentrações de hemoglobina e albumina, e as maiores concentrações plasmática e tecidual de leucotrieno B4 e tecidual de superóxido dismutase do que os groupos tratados com celecoxib. O grupo tratado com cetoprofeno apresentou um comportamento intermediário entre diclofenaco/indometacina e celecoxib, em relação a taxa de sobrevida e albumina. Os grupos sem colite, colite e colite tratado com celecoxib apresentaram menores concentrações de leucotrieno B4 e superóxido dismutase do que os grupos tratados com inibidores não seletivos ciclo-oxigenase 2. Conclusão - Diclofenaco e indometacina apresentaram os maiores graus de exacerbação da colite entre os anti-inflamatórios não-esteróides, o celecoxib não apresentou exacerbação e o cetoprofeno apresenteou um comportamento intermediario entre diclofenaco/indometacina e celecoxib. Estes resultados sugerem que o leucotrieno B4 e superóxido dismutase estão envolvidos na exacerbação da colite experimental pelo anti-inflamatórios não-esteróides não seletivos ciclo-oxigenase 2 .

DESCRITORES - Colite. Anti-inflamatórios não esteróides. Eicosanoides. Estresse oxidativo.

\section{REFERENCES}

1. Aebi VN. Catalase "in vitro". Methods Enzymol. 1984;105:121-6.

2. Ardizzone S, Porro GB. Inflammatory bowel disease: new insights into pathogenesis and treatment. J Intern Med 2002;252:475-96.

3. Barbosa DS, Cecchini R, El Kadri MZ, Rodríguez MA, Burini RC, Dichi I Decreased oxidative stress in patients with ulcerative colitis supplemented with fish oil omega-3 fatty acids. Nutrition. 2003;19:837-42.

4. Barreiro-de Acosta M, Domínguez-Muñoz JE, Núñez-Pardo de Vera MC, Lozano-León A, Lorenzo A, Peña S. Relationship between clinical features of Crohn's disease and the risk of developing extraintestinal manifestations. Eur J Gastroenterol Hepatol. 2007;19:73-8.
5. Breganó JW, Dichi JB, Barbosa DS, El Kadri MZ, Matsuo T, Rodrigues MA, et al. Decreased total antioxidant capacity in plasma, but not tissue, in experimental colitis. Dig Dis Sci. 2009;54:751-7.

6. Cabré F, Fernández MF, Calvo L, Ferrer X, García ML, Mauleón D. Analgesic, antiinflammatory, and antipyretic effects of $\mathrm{s}(+)$-ketoprofen in vivo. J Clin Pharmacol. 1998;38:3S-10S.

7. Cecchini R, Aruoma OI, Halliwell B. The action of hydrogen peroxide on the formation of thiobarbituric acid-reactive material from microssomes or from DNA damage by bleomycin or phenanthroline. Artifacts in the thiobarbituric acid test. Free Radic Res Commun. 1990;10:245-58.

8. Celotti F, Durand T. The metabolic effects of inhibitors of 5-lipoxygenase and of cyclooxygenase 1 and 2 are an advancement in the efficacy and safety of anti-inflammatory therapy. Prostaglandins \& Other Lipid Mediators. 2003;71:147-62. 
9. Cuzzocrea S, Mazzon E, Serraino I, Dugo L, Centorrino T, Ciccolo A, et al Celecoxib, a selective cyclo-oxygenase-2 inhibitor reduces the severity of experimental colitis induced by dinitrobenzene sulfonic acid in rats. Eur $\mathrm{J}$ Pharmacol. 2001;431:91-102.

10. Dichi I, Dichi JB, Frenhane P, Rodrigues MA, Burini RC, Victória CR. Reactivation of ulcerative rectocolitis with drug the use non-steroidal anti-inflammatory: report of a case and review of the literature. Arq Gastroenterol. 1995;32:172-7.

11. Eberhart CE, Dubois RN. Eicosanoids and the Gastrointestinal Tract. Gastroenterology. 1995;109:285-301.

12. El Miedany Y, Youssef S, Ahmed I, El Gaafary M. The gastrointestinal safety and effect on disease activity of etoricoxib, a selective Cox-2 inhibitor in inflammatory bowel diseases. Am J Gastroenterol. 2006;101:311-7.

13. Elson CO, Sartor RB, Tennyson GS, Riddell RH. Experimental Models of inflammatory Bowel Disease. Gastroenterology. 1995;109:1344-67.

14. Feafins LA, Cryer BL. Do Non-steroidal Anti-inflammatory Drugs Cause Exacerbations of Inflammatory Bowel Disease? Dig Dis Sci. 2010;55:226-32.

15. Fraticelli A, Serrano CV Jr, Bochner BS, Capogrossi MC, Zweier JL. Hydrogen peroxide and superoxide modulate leukocyte adhesion molecule expression and leukocyte endothelial adhesion. Biochim Biophys Acta. 1996;1310:251-9.

16. Gabay C, Kushner I. Mechanisms of disease: acute-phase proteins and other systemic responses to inflammation. N Engl J Méd. 1999;340:448-54.

17. Gonzales-Flecha B, Llesue S, Boveris A. Hydroperoxide-initiated chemiluminescence: an assay for oxidative stress in biopsies of heart, liver and muscle. Free Radic Biol Med. 1991;10:93-100.

18. Grisham MB. Oxidants and free radicals in inflammatory bowel disease. Lancet. 1994;344:859-61.

19. Hathaway CA, Appleyard CB, Percy WH, Williams JL. Experimental colitis increases blood-brain barrier permeability in rabbits. Am J Physiol. 1999; 276: 174-80.

20. Hedi H, Norbert G. 5-lipoxygenase pathway, dendritic cells, and adaptive immunity. J Biomed Biotechnol. 2004;2:99-105

21. Isozaki Y, Yoshida N, Kuroda M, Takagi T, Handa O, Kokura S, et al. Effect of a novel water-soluble vitamin $\mathrm{E}$ derivative as a cure for TNBS-induced colitis in rats. Int J Mol Med. 2006;17:497-502.

22. Jentzsch AM, Bachmann H, Fürst P, Biesalski HK. Improved analysis of malondialdehyde in human body fluids. Free Radic Biol Med. 1996;20:251-6.

23. Kandil HM, Argenzio RA, Sartor RB. Low endogenous prostaglandin E2 predisposes to relapsing inflammation in experimental rat enterocolitis. Dig Dis Sci. 1999;44:2110-8.

24. Kethu SR. Extra-intestinal Manifestations of Inflammatory Bowel Diseases. J Clin Gastroenterol. 2006:40:467-75.

25. Klyubin IV, Kirpichnikova KM, Gamaley IA. Hydrogen peroxide-induced chemotaxis of mouse peritoneal neutrophils. Eur J Cell Biol. 1996;70:347-51.

26. Kruidenier L, Kuiper I, Lamers CB, Verspaget HW. Intestinal oxidative damage in inflammatory bowel disease: semi-quantification, localization, and association with mucosal antioxidants. J Pathol. 2003;201:28-36.

27. Kruidenier L, Kuiper I, Van Duijn W, Mieremet-Ooms MA, van Hogezand RA, Lamers CB, Verspaget HW. Imbalanced secondary mucosal antioxidant response in inflammatory bowel disease. J Pathol. 2003;201:17-27.

28. Kruidenier L, Verspaget HW. Oxidative stress as a pathogenic factor in inflammatory bowel disease - radicals or ridiculous? Aliment Pharmacol Ther. 2002;16:1997-2015

29. Kumar S, Ghoshal UC, Aggarwal R, Saraswat VA, Choudhuri G. Severe ulcerative colitis: prospective study of parameters determining outcome. J Gastroenterol Hepatol. 2004;19:1247-52.

30. Leese PT, Hubbard RC, Karim A, Isakson PC, Yu SS, Geis GS. Effects of celecoxib, a novel cyclooxygenase-2 inhibitor, on platelet function in healthy adults: a randomized, controlled trial. J Clin Pharmacol. 2000;40:124-32.

31. Mahadevan U, Loftus EV Jr, Tremaine WJ, Sandborn WJ. Safety of selective cyclooxygenase-2 inhibitors in inflammatory bowel disease. Am J Gastroenterol. 2002;97:910-4

32. Marklund S, Marklund G. Involvement of the superoxide anion radical in the autoxidation of pyrogallol and a convenient assay for superoxide dismutase. Eur J Biochem. 1974;47:469-74.

33. Matuk R, Crawford J, Abreu MT, Targan SR, Vasiliauskas EA, Papadakis KA The spectrum of gastrointestinal toxicity and effect on disease activity of selective cyclooxygenase- 2 inhibitors in patients with inflammatory bowel disease. Inflam Bowel Dis. 2004;10:352-6.

34. Meijer A, Vollaard H, de Metz M, Verbruggen B, Thomas C, Novakova I. Meloxicam, $15 \mathrm{mg} /$ day, spares platelet function in healthy volunteers. Clin Pharmacol Ther. 1999;66:425-30.
35. Meyer AM, Ramzan NN, Heigh RI, Leighton JA. Relapse of inflammatory bowe disease associated with use of nonsteroidal anti-inflammatory drugs. Dig Dis Sci. 2006;51:168-72.

36. Monte M, Davel LE, Sacerdote de Lustig E. Hydrogen peroxide is involved in lymphocyte activation mechanisms to induce angiogenesis. Eur J Cancer. 1997;33:676-82.

37. Morris GP, Beck PL, Herridge MS, Depew WT, Szewczuk MR, Wallace JL. Hapten-induced model of chronic inflammation and ulceration in the rat colon. Gastroenterology. 1989;96:795-803.

38. Muscará MN, Vergnolle N, Lovren F, Triggle CR, Elliott SN, Asfaha S, Wallace JL. Selective cyclo-oxygenase-2 inhibition with celecoxib elevates blood pressure and promotes leukocyte adherence. Br J Pharmacol. 2000;129:1423-30.

39. Niederau C, Backmerhoff F, Schumacher B, Niederau C. Inflammatory mediator and acute phase proteins in patients with Crohn's disease and ulcerative colitis Hepato-Gastroenterol. 1997;44:90-107.

40. Nieto N, Fernandez MI, Torres MI, Ríos A, Suarez MD, Gil A. Dietary monounsaturated n-3 long-chain polynsaturated fatty acids affect cellular antioxidan defense system in rats with experimental ulcerative colitis induced by trinitrobenzene sulfonic acid. Dig Dis Sci. 1998;43:2676-87.

41. Nieto N, Torres MI, Fernández MI, Girón MD, Ríos A, Suárez MD, Gil A. Experimental ulcerative colitis impairs antioxidante defense system in rat intestine. Dig Dis Sci. 2000;45:1820-7.

42. Offer T, Russo A, Samuni A. The pro-oxidative activity of SOD and nitroxide SOD mimics. FASEB J. 2000;14:1215-23.

43. Podolsky DK. Medical Progress: Inflammatory Bowel Disease. N Engl J Med 2002;347:417-29.

44. Power I, Chambers WA, Greer IA, Ramage D, Simon E. Platelet function after intramuscular diclofenac. Anaesthesia. 1990;45:916-9.

45. Pravda J. Radical induction theory of ulcerative colitis. World J Gastroentero.l 2005;11:2371-84.

46. Reuter BK, Asfaha S, Buret A, Sharkey KA, Wallace JL. Exacerbation of Inflammation-associated Colonic Injury In Rat Through Inhibition of Cyclooxygenase-2. J Clin Invest. 1996;98:2076-85.

47. Rijnierse A, Koster AS, Nijkamp FP, Kraneveld AD. Critical role for mast cells in the pathogenesis of 2,4-dinitrobenzene-induced murine colonic hypersensitivity reaction. J Immunol. 2006;176:4375-84

48. Sartor RB. Pathogenesis and immune mechanisms of chronic inflammatory bowe diseases. Am J Gastroenterol. 1997;92:5S-11S

49. Singh VP, Patil CS, Jain NK. Aggravation of inflammatory bowel disease by ciclooxygenase-2 inhibitors in rats. Pharmacology. 2004;72:77-84

50. Stichtenoth DO, Tsikas D, Gutzki FM, Frölich JC. Effects of ketoprofen and ibuprofen on platelet aggregation and prostanoid formation in man. Eur J Clin Pharmacol. 1996;51:231-4.

51. Takeuchi K, Smale S, Premchand P, et al. Prevalence and mechanism of nonsteroidal antiinflammatory bowel disease. Clin Gastroenterol Hepatol. 2006;2:196-202.

52. Tissot B, Lamy A, Perraudeau F, Manouvrier JI, Imbert Y.Colite aiguë avec fistule recto-vaginale sous anti-inflammatoires non stéroïdiens. Presse Med. 2002;31:1131-3.

53. Wallace JL, Keenan CM, Gale D. Exacerbation of Experimental colitis by nonsteroidal anti-inflammatory drugs is not related to elevated leukotriene B4 synthesis. Gastroenterology. 1992;102:18-27.

54. Wallace JL, Ma L. Inflammatory mediators in gastrointestinal defense and injury. Exp Biol Med. 2001;226:1003-15

55. Wallace JL, McKnight W, Reuter BK, Vergnolle N. NSAID-Induced gastric damage in rats: requirement for inhibition of both cyclooxygenase 1 and 2 . Gastroenterology. 2000;119:706-14

56. Wallace JL. Prostaglandin biology in inflammatory bowel disease. Gastroenterol Clin North Am. 2001;30:971-80.

57. Warner TD, Giuliano F, Vojnovic I, Bukasa A, Mitchell JA, Vane JR. Nonsteroid drug selective for cyclo-oxigenase-1 rather than cyclo-oxigenase-2 are associated with human gastrointestinal toxicity: a full in vitro analysis. Proc Natl Acad Sci USA. 1999;96:7563-8.

58. Warner TD, Mitchell JA. Cyclooxigenases: new forms, new inhibitors, and lessons from the clinic. FASEB J. 2004;18:790-804.

59. Zhang L, Lu YM, Dong XY. Effects and mechanism of selective COX-2 inhibitor, celecoxib, on rat colitis induced by trinitrobenzene sulfonic acid. Chin J Dig Dis 2004;5:110-4. 